\title{
Reducing Pregnant Woman's Anxiety in Dealing with Delivery through Guided Imagery Therapy
}

\author{
Jupriyono* \\ * Health Polytechnic of Malang, Republic of Indonesia
}

\begin{abstract}
The woman in labor will normally feel fear and anxiety. These conditions will obviously create impact on the process of delivery and can eventually prolong the time of delivery of both first stage and second stage. Furthermore, bleeding at post partum will likely be inevitable. Women's anxiety during delivery can be managed through guided imagery therapy in which their imaginations are specially designed to bring about potentially positive effect. The research aims to identify the effectiveness of guided imagery therapy towards women's anxiety in delivery. The research deployed pre experiment design with one group pre-post test design. Samples's collection was carried out through accidental sampling in which 22 pregnant women of primigravida which met the inclusion criteria. Data collection of anxieties was conducted through questionnaire distribution of HARS scale, then the data was analyzed using the distribution of frequency and test of Paired t-test. The research result indicated that $27,27 \%$ of respondents suffered from mild anxiety and $72,73 \%$ of them suffered from moderate anxiety, and after the guided imagery therapy 36,36\% of respondents felt no more anxiety and $54,55 \%$ of respondents experienced light anxiety. From the analysis, result of paired t-test value was obtained $t_{\text {count }}=20,514$ and $t_{\text {tablel }}=2,228$, and value $p=0.000$, then $H_{0}$ was rejected. The research concluded that guided imagery therapy effecetively reduced pregnant women's level of anxiety in delivery.
\end{abstract}

Keywords: Delivery, Anxiety, Guided Imagery Therapy

\section{Introduction}

Delivery is such a physiological process which enables expectant mothers (pregnant women) to experience a wide range of profound transformation during the delivery (Yessi, 2010). An expectant mother always wishes for perfectly normal process of delivery with physically safe and healthy condition of the mother and the infant. Expectant mothers' death rate remains a major problem in Indonesia, and according to statistical data in 2007 the death rate reached $227 / 100.000$ of living birth which means 35 expectant mothers pass away each day due to delivery. Therefore, to welcome MDGs 2015 women's death rate of delivery was targeted to decrease to $102 / 100.000$ of living birth. The major cause of women's death during delivery is $42 \%$ due to post delivery severe bleeding then followed by eclampsia and infection. Delivery bleeding was among others due to long delivery process which was caused by expectant mothers' fear and anxiety during the delivery ( Prawiroharjo, 2007).

Psychological problem also contributes to factors which play a pivotal role during the delivery process out of other factors such as powers, passageway, passanger, helper, position and companion. Physical and psychological changes are regularly experienced by expectant mothers and therefore preparation to deal with each factor needs to be taken prior to delivery. Psychological factor occurs when the expectant mothers are not ready and even do not understand the delivery process. Midwives have to provide the expectant mothers with careful guidance to prepare delivery process to run well and normal. Midwives also need to take actions by leading, supporting to improve expectant mothers' comfort, and preparing their psychological condition through various safe and peaceful interventions.

The data collected from the Department of Health of Malang indicated that in 2011, 90\% patients taken care in Midwife Independent Practice (PBM) were refered to a number of private hospitals in Malang and underwent Sectio Caesaria surgery (SC). Many factors influenced the delivery process eventually ended up in Sectio Caesaria surgery (SC). However, from a number of interviews with many midwives, it was revealed that the delivery took long process due to expectant mothers' fears, anxieties and pains.

The risks of delivery are mostly due to long partus or time of delivery prolongation (Pramita, 2009). As a matter of fact, psychological factor is one of factors which influence good process of delivery. Expectant mothers of primigravida normally are not yet prepared and do not have any ideas of what would happen at the end of their pregnancies and delivery. Expectant mothers' anxiety can reduce the quality of blood's transport to womb. Less quality of contraction in the womb will likely cause the slowness of delivery (long delivery), the decrease of blood's currency towards placenta, the drop of oxygen supply to infant, the increase of infant's Catecholamines production, and the increase of perception of negative woman. Moreover, Chapman (2000) indicated that the major cause of long partus was stressed response. 
According to the research result conducted by Yessi (2010) that expectant mother's anxiety and long process of delivery showed significant correlation with the value of $r_{s} 0,701$. In other words, expectant mothers with severe anxiety will likely need more time in the process of delivery. Anxiety can be handled through self control, supports, physical actions, sleep, music, and guided imagery therapy (Savitri, 2003). Guided imagery is a process implemented to nerve system to express sensation of relaxation. During the treatment, clients were suggested to concentrate to imagine for a better relaxation (Delaune,2002).

Expectant mothers' preparation for delivery should be started since pregnancy firstly detected and in a regular impelementation for effective results. A number ways to prepare the expectant mothers for delivery could be carried out such as the knowledge of pregnancy counseling; delivery and its influential factors, circumstance to occur during the delivery, pregnancy work-out and guided imagery therapy. Guided imagery therapy will provide expectant mothers with spiritual emotion such as supports and notable examples of women with delivery experience.

\section{The Conceptual Framework}

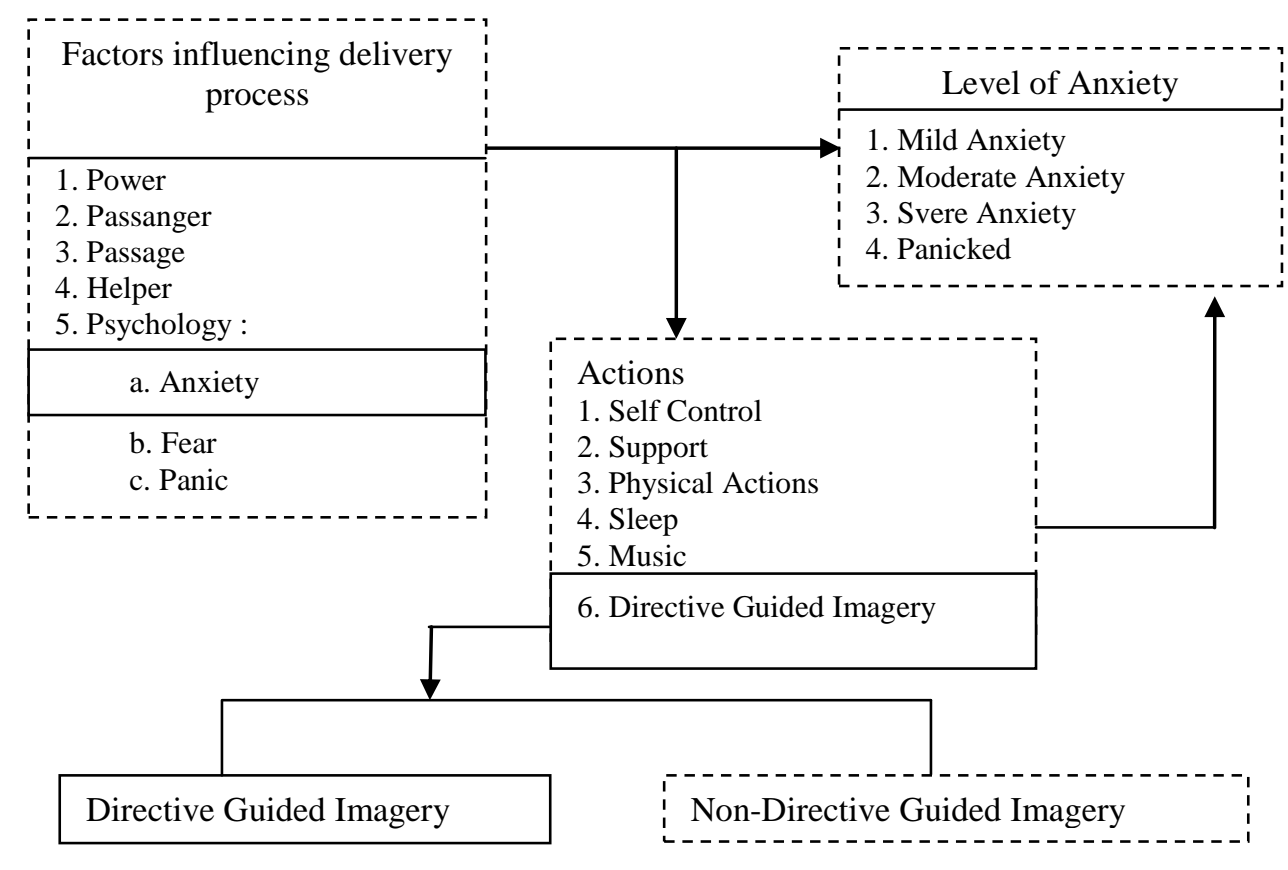

Notes:

\begin{tabular}{|ll}
\hline & Under Research \\
$-\ldots+-$ & Not Under Research
\end{tabular}

Figure (1) Chart of Conceptual Framework and Model Analysis

\section{General Objective}

Identifying the impact of guided Imagery therapy towards the decrease of expectant mothers' anxiety in delivery

\section{Specific Objective}

1. Identifying expectant mothers' anxiety prior to guided imagery.

2. Identifyng the expectant mothers' anxiety post guided imagery.

3. Analysing the impact of guided imagery in decreasing the expectant mothers' in delivery.

\section{Design}

\section{Research Method}

The research design was pre exsperimental with One Group pre test-post test design. The characteristic of research with One Group pre test-post test is that cause and effect correlation isrevealed throughgroup of subject involvement.Thus, prior to preliminary data collection (pre test), then post treatment another measurement was conducted to identify the effect of treatment (post test). The research design is illustrated in figure (2): 


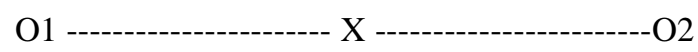

Note:

O1 : The test of expectants mother's anxiety prior to the treatment of directive guided imagery therapy terapi imajinasi terbimbing

$\mathrm{X}$ : The treatment of "Directive guided imagery therapy"

$\mathrm{O} 2$ : The test of expectants mother's anxiety posttreatment of directive guided imagery therapy terapi imajinasi terbimbing

Figure (2): Research Design

\section{Population and samples}

The research population was 32 expectant mothers in Ante Natal Care at BPS "S" in municipality of Batu City, East Java Province from July to October 2012. The total calculation of the research samples used Slovin's formula: (Notoatmodjo, 2005). According to calculation 22 samples were collected.

\section{Technic Sampling}

The research samples were 22 expectant nullipara joinning the class of pregnant women. The research deployed sample collection technic through non probability sampling with accidental sampling technique.

\section{Research Variables}

1. Independent variable; guided imagery therapy $(\mathrm{X})$ : is such a nursing treatment by assisting expectant mothers in the delivery process by imagining positive circumstances through recorded voice of guided imagery therapy played in a recording tool connected to speaker in the duration of 5-10 minutes during no uterus contractions.

2. Dependent variable; expectant mothers' anxiety in dealing with delivery (Y): is such an individual response towards unpleasant circumstances experienced by expectant mothers especially during the delivery conveyed through questionnaires of HARS scale provided by the researcher.

\section{Research Hypothesis}

H1 : Guided imagery therapy can decrease expectant mothers' anxiety in delivery

\section{Data Analysis}

To identidy the impact of guided imagery therapy towards expectant nullipara by observing the significant difference between pre test and post test score, then analysing the difference of anxiety using statistical test Paired $t$ Test with the support of SPSS 16 for Windows and level $\alpha \leq 0,05$ (Fajar, dkk, 2009).

\section{Research Code of Ethic}

1. The research obtained the letter of recommendation namely "Etical Clearance" from Commission of Ethic of Health Research, Polytechnic of Health, the Ministery of Health of Malang.

2. Informed consent has been distibuted to all respondents

3. The confidentiality of respondents' data is strongly guaranteed

\section{Result}

Table (1) Respondents' Characteristics in BPM of Batu City

\begin{tabular}{|c|c|c|c|}
\hline No. & Education & $\mathbf{x}$ & \% \\
\hline 1 & Elementary & 10 & $45,45 \%$ \\
\hline 2 & Junior High & 4 & $18,18 \%$ \\
\hline 3 & Senior High & 6 & $27,27 \%$ \\
\hline 4 & University & 2 & $9,1 \%$ \\
\hline
\end{tabular}

Table 1 shows that only $9.1 \%$ of respondents completed university degree, whereas the majority of them $(45.45 \%)$ just passed the elementary level

Table (2) Anxiety Frequency Distribution Pre and Post Guided Imagery Therapy

\begin{tabular}{|c|c|c|c|c|c|}
\hline \multirow{2}{*}{\multicolumn{2}{|c|}{ Anxiety Level of Pregnant Women }} & \multicolumn{2}{|c|}{ Pre } & \multicolumn{2}{|c|}{ Post } \\
\hline & & f & $\%$ & f & $\%$ \\
\hline 1. & No Anxiety & 0 & $0 \%$ & 8 & $36,36 \%$ \\
\hline 2. & Mild Anxiety & 6 & $27,27 \%$ & 14 & $54,55 \%$ \\
\hline 3. & Moderate Anxiety & 16 & $72,73 \%$ & 0 & $0 \%$ \\
\hline \multirow[t]{2}{*}{4.} & Severe Anxiety & 0 & $0 \%$ & 0 & $0 \%$ \\
\hline & Total & 22 & $100 \%$ & 22 & $100 \%$ \\
\hline
\end{tabular}

Table 2 shows that prior to the guided imagery therapy $27.27 \%$ of respondents experienced mild anxiety and $72.73 \%$ experienced moderate anxiety, but after the therapy $36.36 \%$ of respondents do not experience anxiety and $54,55 \%$ of respondents experienced mild anxiety. 


\section{Test Results Statistics}

In the t-test using $\alpha(0.05)$ and $\mathrm{dk}=10$ it was obtained the value of $\mathrm{t}=20.51, \mathrm{t}$ table $=2.228$ and $p=0.000$. Therefore, the $\mathrm{H} 1$ is accepted meaning that guided imagery therapy is an effective means to reduce maternal anxiety in labor.

\section{Discussion}

Childbirth is a crucial time experienced by pregnant women. Vairous factors affecting labor for mother and baby among others: the power of the mother (contractions) as the evidence of nutritional adequacy prepared for labor. In addition to the power, the passageway (birth canal) which is divided into two types, namely soft and hard birth canal. The birth canal is composed of the mother's rigid bony pelvis and the soft tissues of the cervix, pelvic floor, vagina and introitus (the external opening to the vagina). The pelvic canal varies in size and shape at various levels. The diameters at the plane of the pelvic inlet, midpelvis, and outlet, plus the axis of the birth canal determine whether vaginal birth is possible and the manner by which the fetus may pass down the birth canal. The subpubic angle, which determines the type of pubic arch, together with the length of the pubic rami and the intertuberous diameter, is of great importance. Because the fetus must first pass beneath the pubic arch, a narrow subpubic angle will be less accomodating than a rounded, wide arch. Baby in labor factor (Passenger) also affects the labor. The way the passengr, or fetus, moves through the birth canal is determined by several intercating factors: the size of the fetal head, fetal presentation, fetal lie, fetal attitude, and fetal position. Skillful and competent labor assistant must be qualified in accordance with the regulation of Helath Minitser (Permenkes) 1464 / X / 2010 in order to provide a good service quality.

Another crucial factor is psychological factor which turns out to be very dominant influence in labor. Laboring process can be slow-moving when the laboring mother feels uncomfortable, anxious, and fearfull which possibly will affect the inertia of uterine contractions. Uterine inertia impact also affects the first stage, second stage, and the third stage of labor with the occurrence of retained placenta and even more dangerous effect on the fourth stage with the atonic uterus and result in postpartum hemorrhage. Feelings of fear and anxiety in laboring process are almost experienced by some mothers in labor. Anxiety and fear felt as a mother concerned about the state of the delivary, and also her ability to endure the pain she will have in the labor.

Education is another contributive factor influencing maternal anxiety in laboring process. Table 1 indictaes that $45.45 \%$ of respondents from elementary education level experienced moderate anxiety and $27.27 \%$ of respondents from high school education experience mild anxiety. The difference in the level of anxiety varies among mothers in labor depending on their level of understanding and knowledge upon the birth process itself. The nescience of a thing in labor was considered as a pressure leading to a crisis and can cause anxiety. According Raystone, in Meria (2005), the one's level of education is influential in giving a response to something that comes from inside and outside. People who have higher education will provide a more rational response than those with lower educated or uneducated.

Anxiety in pregnant women in laboring process prior to the guided imagery therapy is shown in Table 2. First, no respondent found themselevs not anxious (0\%), but after the intervention $36.36 \%$ of them did not feel anxious anymore. Wheras $27.27 \%$ of respondents experiencing mild anxiety prior to the therapy incresed gradually to $54.55 \%$. Respondents with moderate anxiety prior to the therapy were as much as $72.73 \%$, but after the intervention no one in this level of anxiety $(0 \%)$. A decrease in anxiety in this study was due to the respondents' various responses on how respondents coped with the problems they encountered. This is in accordance with the opinion of Stuart \& Sundeen (1996) who said that anxiety was always dynamic shifted from time to time depending on the response of each individual.

Guided imagery can reduce the anxiety of women in the delivery since it will guide a person into a relaxed state and visualizing themselves in a pleasant, happy situation. According to Delaune (2002), the imagery will be accepted as stimulation by the senses and then driven to the brainstem at the thalamus sensor. In the thalamus the imagery is then classified based on the language of the brain, and then a small portion stimulus will be transmitted to the amygdala and hippocampus. The hippocampus plays as a determinant role of sensory signals which then considers its importance. If the hippocampus decides the incoming signal important then it will be stored in memory. When a stimulus causes a favorite imagery to appear, the saved memory of similar experience will be recalled in the form of a relieving anxiety.

The knowledge and competence of a midwife is also an additional factor in maternal anxiety. If the midwife really masters the concepts of labor which is a natural process, she will be able to provide a counseling to a mother in labor to have a better understanding about it. A clear understanding and a broad knowledge of labor will make her understand how to behave to the current state of childbirth.

An alternative method may be offered is by providing effective counseling and health education through the concept of "dear mother and baby" and assessement of their needs and readiness in dealing with problems. In order to prepare for safe and comfortable childbirth through this concept, it is necessary to plan an intervention to mothers and infants for the purpose of taking a well care of childbirth and protecting both the 
mother and the baby from potential problems or complications. This concept of 'dear mother and baby' will support the emotion and psychology of a mother in labor by which the plan of delivery care should be explained properly to the mother and her family. As a result they will understand the benefits and what anticipation should be taken to avoid the mother and baby from the various disturbances that may threaten safety or quality of life. Maternal anxiety can be overcome or minimized through the psychological support of maternal affection care by appreciating the culture, beliefs and desires of the mother.

The other principle of the maternal affection care is by involing the husband and the family during the labor and childbirth. The study conducted by Enkin (2000) concluded that if the mother was cared for and given support during labor and childbirth and knew about the process of childbirth and the care to be received, the mother would feel safe, comfortable and relaxed. The 'dear mother and baby' care would reduce the occurrence of labor to the further action; such as vacuum delivery, forcep delivery, and sectio caesaria. In addition, other concept of maternal care to reduce anxiety is through guided imagery therapy. Imagery guided therapy is the use of someone's imagination in a way that is designed specifically to achieve certain positive effects. With eyes closed, individuals are instructed to imagine in a slow in-exhaled breath, muscle pain and discomfort will relieve, causing the body relaxed and comfortable.

From the previous explanation it can be summed up that guided imagery therapy is an alternative to reduce the anxiety of pregnant women in the laboring process. In this study, "Guided Imagery Therapy" turned out to be very effective for pregnant women to decrease anxiety in the laboring process through the mechanism of a diversion (distraction) and control over the feeling of comfort that bring out the feeling of calm (relaxation). Listening to the sound and music is one of the guided imagery techniques in which a person will be guided by words to imagine the things that bring peace of mind and become more calm and comfortable.

Effective and sustainable counseling and health education can also affect the understanding of respondents to accept or adapt the labor, by that way it will greatly contribute to lower levels of anxiety. A midwife is the following factor emerging in maternal anxiety, especially when pregnant women have entered the laboring process. Competent midwife with her persuasive approach through coomunicative therapeutic will greatly assist mother in labor passes through the childbirth safely and conveniently. A midwife with good knowledge and awareness of the birth process will help provide education on maternal health by providing appropriate counseling and support to a mother in labor as well as her family.

One thing to be considered by a husbands and his family when his wife is in labor is how to give support both physically and psichologically in order that she feels very taken care and appreciated. This is very important because psychological factors are very dominant the childbirth. They significantly affect maternal power which is going to predispose the length of labor. A woman in labor involve various psychological states such as being relieved, being excited, being disappointed or being evasive. They feel very curious about new responsibilities, can not wait to whip out the placenta, have a willingnes to get further medical action or vice versa, feel rigid to be closer to her husband and her baby, do not even like new condition. Psichological changes of pregnant mothers commonly seen are emotional, irritable, and sensitive, frustrated, sentimental, hateful or even affective. Pregnancy can be accepted with pride, joy or it could be even disappointing when it is not ready to get pregnant. According to Gary (2002) in Novaria (2009), during labor or delivery, women will experience anxiety about the baby and the childbirth that need to be seriously taken care. This anxiety may be due to childbirth pain, abnormalities at birth, the effects of uterine contractions, and dilatation of the cervix.

In order to be able to take care of the labor and everything that possibly occur during childbirth, pregnant women need to prepare mentally and psychologically and their family provide support to them in the childbirth. Therefore any method to support the psichology and mental of both the mother and the family should be perfectly prepared and one of them is by guided imagery therapy.

\section{Conclusion}

\section{Conclusions and Recommendations}

This study revealed that there were differences in anxiety levels of pregnant women prior to and after the intervention. It was found that guided imagery therapy was an effective means to reduce anxiety level of pregnant women in laboring process.

\section{Recommendation}

Based on the conclusion of the study, some suggestions are expected to be useful for practical use and further research.

\section{For Further Research}

This study can be a useful reference for further research in the development of science and research especially in psychological aspects the expectant mothers have in labor.

\section{For Health Workers}

This study can be as inputs for midwives to improve the service especially in providing psychological support the expectant mothers need in labor. 


\section{For Community}

The involvement and support of husband and other family members lead to the success of a delivery. One of them is through this guided imagery therapy for pregnant women which is practicable at home. This therapy will be more effective when it is carried out by both husbands and wives, because the success of the delivery process will inevitably involve them both.

\section{References}

[1]. Chapman, V. 2006. Asuhan Kebidanan Persalinan Dan Kelahiran, (terjemahan). Jakarta: EGC

[2]. Delaune . S. C. And Ladner, P. K. 2002. Fundamentals of Nursing Standar and Practice. $2^{\text {nd }}$ Edition. USA : Thomson - Delmar Learning.

[3]. Enkin, 2002. Guided Imagery That Heal., The U.S Journal Inc. http://www.counselormagazine.com /content/view/189/63/ diakses tanggal 20 Maret 2012 jam 14.33 WIB

[4]. $\quad$ Fajar ,dkk. 2009. Statistik Untuk Paraktisi Kesehatan. Yogyakarta : 2009.

[5]. Meria. 2005. Teori Kecemasan http://perawatpskiatri.blogspot.com/2009/03/teori-kecemasan.html diakses tanggal 31 maret 2012 jam 07.05 WIB

[6]. Notoatmodjo, (2005). Pendidikan dan Perilaku Kesehatan. Jakarta : Rineka Cipta

[7]. Novaria A.I \& T.P. Budi. 2009. Buku Pintar Kehamilan: Persiapan Hamil Hingga Menyusui. Yogyakarta : Oryza

[8]. Pramita. 2009. Faktor Yang Mempengaruhi Persalinan. http://pramitaherlina.blogspot.com/2009/09/ ho-faktor-yangmempengaruhi-persalinan.html diakses tanggal 31 Maret 2012 jam 07.40 WIB

[9]. Prawirohardjo, 2006. Ilmu Kebidanan. Jakarta: Yayasan Bina Pustaka Sarwono Prawirohardjo.

[10]. Savitri. 2003. Kecemasan : Bagaimana Mengatasi Kecemasan. Jakarta : pustaka Populer Obor

[11]. Sheila. 2008. Buku Ajar Keperawatan Jiwa. Jakarta: EGC.

[12]. Smeltzer, Suzanne C. dan Brenda G. Bare. 2001. Buku Ajar Keperawatan medikal Bedah Brunner \& Suddarth. Jakarta : EGC.

[13]. Yessi. 2008. Kecemasan atau Ansietas. http://www.mitrariset.com/2008/11/kecemasan-atau-ansietas.html diakses tanggal 31 Maret 2012 jam 07.45 WIB. 